\title{
Postharvest quality of strawberry produced during two consecutive seasons
}

\author{
Marina C Antunes ${ }^{1}$; Francine L Cuquel ${ }^{1}$; Maria AC Zawadneak ${ }^{1}$; Átila F Mogor ${ }^{1}$; Juliano TV Resende ${ }^{2}$ \\ ${ }^{1}$ UFPR, C. Postal 19061, 81531-990 Curitiba-PR; francine@ufpr.br (autor para correspondência); ${ }^{2}$ UNIOESTE-CEDETEG, C. Postal \\ 3010, 85040-080 Guarapuava-PR
}

\begin{abstract}
Maintaining plants in the field for two consecutive crop cycles is one of the latest techniques used by strawberry growers to reduce production costs. The goal of this research was to evaluate the postharvest fruit quality of six strawberry cultivars produced for two consecutive seasons with the same plants. They were planted from May to July 2010 under low-tunnel and fruits were evaluated in two growing seasons (season 1= January, February, and March 2011 and season 2=August, September, and October 2011), totaling three harvests of each cultivar in each year season. Fruits were picked up randomly among 500 plants of each cultivar, organized into five replications of five fruits and kept for three days before analysis under refrigeration (average temperature of $4^{\circ} \mathrm{C}$ ). Variables analyzed were: soluble solids content, titratable acidity, soluble solids content/titratable acidity, flesh firmness, $\mathrm{C}$ vitamin content, sensory characteristics (sweetness, flavor, acidity, aroma, shape and flesh firmness), and mineral composition ( $\mathrm{Ca}, \mathrm{Fe}, \mathrm{K}, \mathrm{Mg}, \mathrm{Mn}, \mathrm{Cu}$ and Zn). 'Albion', 'Monterey' and 'San Andreas' showed good physical, chemical and sensory characteristics in both seasons. In general, fruits produced during the season 1 showed better physical, chemical and sensory characteristics than fruits produced in season 2. 'Palomar' and 'Portola' were better than the other cultivars concerning $\mathrm{C}$ vitamin content in both seasons. 'Palomar' showed higher potassium, calcium, magnesium, manganese and zinc levels, and 'Portola' showed higher calcium and iron levels.
\end{abstract}

Keywords: Fragaria x ananassa, sensorial analysis, antioxidant, minerals, functional food, $\mathrm{C}$ vitamin.

\section{RESUMO}

Qualidade pós-colheita de morango produzido durante dois ciclos consecutivos

Uma das tecnologias recentes utilizadas pelos produtores de morango visando reduzir os custos de produção é a manutenção das plantas a campo por dois ciclos consecutivos, propiciando duas safras com a mesma muda. O objetivo desta pesquisa foi avaliar a qualidade pós-colheita dos frutos de seis cultivares de morango durante dois ciclos consecutivos com a mesma muda. As mudas foram plantadas de maio a julho de 2010 sob túnel baixo e os frutos foram avaliados em duas épocas (época 1= janeiro, fevereiro e março de 2011; época $2=$ agosto, setembro e outubro de 2011), totalizando três colheitas de cada cultivar em cada época do ano. Os frutos foram colhidos de forma aleatória dentre 500 plantas de cada cultivar, organizados em cinco repetições de cinco frutos e mantidos por três dias sob refrigeração (temperatura média de $4^{\circ} \mathrm{C}$ ). As variáveis analisadas foram teor de sólidos solúveis, acidez titulável, relação teor de sólidos solúveis/acidez titulável, firmeza de polpa, teor de vitamina $\mathrm{C}$, características sensoriais (doçura, sabor, acidez, aroma, formato e firmeza de polpa) e composição mineral ( $\mathrm{Ca}, \mathrm{Fe}, \mathrm{K}, \mathrm{Mg}, \mathrm{Mn}, \mathrm{Cu}$ e Zn). As cultivares Albion, Monterey e San Andreas destacaram-se quanto às suas características físicas, químicas e sensoriais nas duas épocas de cultivo. De maneira geral, os frutos produzidos na época 1 apresentaram melhores características físicas, químicas e sensoriais que os frutos produzidos na época 2. As cultivares Palomar e Portola destacaram-se das demais quanto ao teor de vitamina $\mathrm{C}$ nas duas épocas de cultivo. Palomar destacou-se quanto aos teores de potássio, cálcio, magnésio, manganês e zinco e a cultivar Portola quanto aos teores de cálcio e ferro.

Palavras-chave: Fragaria $\mathrm{x}$ ananassa, análise sensorial, antioxidante, minerais, alimento funcional, vitamina $\mathrm{C}$.

\section{(Recebido para publicação em 2 de maio de 2013; aceito em 7 de abril de 2014)}

(Received on May 2, 2013; accepted on April 7, 2014)

$\mathrm{S}^{\mathrm{t}}$ trawberry harvest begins at approximately $60 / 80$ days after transplanting plantlets to the field (Cantillano, 2005). One of the recent techniques used by strawberry growers is the biennial crop replanting, in which plants are maintained in the field for two consecutive cycles, allowing two crops with the same plants at Season 1 (January, February and March) and Season 2 (August, September and October), which reduces cost, because plantlets are one of the main costs of strawberry production (Oliveira \&
Scivittaro, 2009).

One of the obstacles for the strawberry production is the low number of cultivars available (Oliveira et al., 2008). 'Camino Real' (short-day cultivar) and 'Albion' (day-neutral cultivar), from the University of California Breeding Program, are important cultivars in Southern Brazil. However, other cultivars from the same origin are also occasionally planted, but with very little information about their field performance (Oliveira et al., 2006; Antunes et al., 2010), what is even more relevant when considering the biennial crop replanting.

Attributes such as fruit size, texture, presence of functional compounds and C-vitamin content depend on genetic and environmental factors and should be considered in the selection of new cultivars (Camargo et al., 2011; Silva et al., 2013; Basu et al., 2014). The food composition has been a frequent focus of researches seeking to identify nutritional differences among cultivars (Tulipani et al., 2008; Cantillano et al., 2012), and also among cultivation techniques 
(Darolt, 2003; Cantillano et al., 2012).

Also, strawberry fruits must present good acceptance by the consumer market, because choosing, at the purchase act, is generally based on fruit appearance, but the decision towards buying the same product again depends mainly on the flavor (Kader, 1999). Sensory analysis appears to be an important tool in evaluating the quality of food products (Ferreira et al., 2000). Simple instrumental measurements are not able to predict the sensory characteristics of strawberry cultivars (Vicente et al., 2014). However, few scientific articles studying fruit quality have included sensory evaluations, due to difficulties concerning the judges selection and training, as well as the ethical issues related to researches involving human beings.

Among the sensory analysis methods available to measure the preference of consumers, the Quantitative Descriptive Analysis (QDA) is probably the most widely used method due to the reliability and validity of its results, in addition to its simplicity of execution. The result of evaluating QDA is converted into numerical scores, which are statistically analyzed to determine the preference for a specific sample from the evaluated set (Dutcoski, 2007).

The goal of this research was to evaluate the postharvest fruit quality of six strawberry cultivars (Albion, Camino Real, Palomar, Portola, Monterrey and San Andreas) produced for two consecutive seasons with the same runners.

\section{MATERIAL AND METHODS}

This study was carried out in a commercial strawberry farm operating in an Integrated Production Management, under low tunnel structure, in 2010/11, located in São José dos Pinhais, Metropolitan Region of Curitiba (CMR), Paraná state, Brazil (2536'48'S, 4904'55'W, $932 \mathrm{~m}$ altitude).

Strawberry seedlings of 'Camino Real' and 'Palomar' (short-day cultivars) were transplanted in May 2010 and 'Albion', 'Portola', 'Monterey' and 'San Andreas' (day-neutral cultivars) were transplanted in July 2010. These seedlings were transplanted to 33 beds measuring $6 \mathrm{~m}$ long, $1 \mathrm{~m}$ wide and 0.5 $\mathrm{m}$ high, and they were set out $0.3 \mathrm{~m}$ apart. Twenty days before transplanting, soil was fertilized with $60 \mathrm{~g} \mathrm{~m}^{2}$ of NPK formula 4-12-8. After that, fertilization was applied weekly, beginning 15 days after transplanting, by fertigation with $12 \mathrm{~kg} \mathrm{ha}^{-1}$ of NPK 15-30-15.

Physico-chemical, $\mathrm{C}$ vitamin content, and sensory analyses were carried out with fruits harvested in 2011 during two growing seasons (season $1=$ in January, February and March and season 2= in August, September and October), in a total of three samples of each cultivar from each season. Fruits were harvest at $75 \%$ of the external surface with red color. The harvest was carried out from 8 to $10 \mathrm{AM}$; fruits were picked randomly among 500 plants of each cultivar. The physico-chemical analyses were made with 25 fruits of each cultivar. Fruits were organized into five replications of five fruits and kept for three days before analysis under refrigeration (average temperature of $\left.4^{\circ} \mathrm{C}\right)$.

Physico-chemical characteristics evaluated were titratable acidity (TA), soluble solids (SS), both according to the methodology described by Horwitz \& Latimer (2005). These analyses provided the values for calculating the SS/TA ratio. Fruit firmness was measured using Brookfield CT3 Texture Analyzer with a probe of $2 \mathrm{~mm}$ of diameter, $5 \mathrm{~mm}$ of penetration at speed of $5 \mathrm{~mm} \mathrm{~s}^{-1}$.

$\mathrm{C}$ vitamin content was evaluated as recommend by Horwitz \& Latimer (2005). Twenty fruit samples of each cultivar were randomly taken from the studied area on January, February and March and on August, September and October. Fifty grams of $2 \%$ oxalic acid was added to $25 \mathrm{~g}$ of each sample. After that, 20 grams of this solution were taken out and transferred to a 50 $\mathrm{mL}$ volumetric flask and filled with oxalic acid. The titration was done with DCFI (2.6, dichlorophenol-indophenol) and with the solution described above, which was filtered in paper, an aliquot of $10 \mathrm{~mL}$ being withdrawn for analyzes. Results were expressed in milligrams of ascorbic acid per $100 \mathrm{~g}$ of sample.

Sensory analysis was undertaken with 55 people, who were strawberry consumers and interested in participating on a regular basis of this strawberry sensory analysis. The project aim was explained to the participants when they were first contacted, as well as the importance of their participation, the meanings of sensory analysis terminology, and how the evaluations would be made by QDA methodology, as recommended by Dutcoski (2007).

QDA form containing an unstructured scale of $10 \mathrm{~cm}$ for each of the attributes to be evaluated: sweetness, flavor, acidity, aroma, shape, and flesh firmness was presented to each participant. They were trained to register their strawberry opinions on the QDA form from bad to good. These fruits were previously cleaned under running tap water. After training, 22 judges were selected, those that had a higher sensibility and perception for judging each attribute, as recommended by Dutcoski (2007).

During sensory analysis each strawberry cultivar was analyzed three times in each year season. Judges received three samples of five fruits of each cultivar, which were identified by code. Scores given on the QDA scale were converted into numerical scores and analyzed statistically to determine the samples preferences (Dutcoski, 2007). This research in accordance to the ethical research on human beings was approved by the Ethics Committee of the Federal University of Paraná under the number 0950.075.10.06.

For mineral analysis, twenty fruits of each cultivar were randomly harvested in August 2011 and submitted to the analysis of calcium, potassium, manganese, magnesium, iron, copper and zinc, according to Martins \& Reissman (2007). For these analyses, fruits were dehydrated in oven at $60^{\circ} \mathrm{C}$ during approximately five days and grounded in coffee grinder MDR301Cadence, then a sub-sample of $1 \mathrm{~g}$ was extracted for calcination at $550^{\circ} \mathrm{C}$ and solubilization in $3 \mathrm{M} \mathrm{HCl}$. Elements were determined with conventional atomic absorption spectrophotometer with air/acetylene flame.

Results were submitted to variance 
analysis and cultivars were compared to each other and within each season by Tukey $1 \%$.

\section{RESULTS AND DISCUSSION}

All cultivars produced fruits during season 1 with higher soluble solids contents than those produced during season 2 (Table 1). This may be explained because plants kept in the field during more than 12 months (season 2) are less vigorous than those harvested sooner (Oliveira et al., 2006). During season 1 'Albion' fruits showed the highest soluble solids content, followed by 'Monterrey'. During season 2 'Palomar' fruits kept this feature, followed by 'Albion' fruits (Table 1).

All strawberry cultivars, in both seasons, showed lower soluble solids content (Table 1) than those levels observed in other strawberry cultivars (Conti et al., 2002; Resende et al., 2008), and also none of them showed at least $7 \%$ soluble solids content, the minimum amount recommended for strawberry flavor acceptance (Kader, 1999).

All cultivars acidity, in both seasons, was higher than $0.8 \%$, the maximum recommended for strawberry flavor acceptance (Kader, 1999). The high fruit acidity in season 1 can be attributed to the high summer temperatures and to the long days, condition under which plants emit stolon that, every two nodes (in general), emits new leaves and roots (Filgueira, 2008). The high acidity in season 2 can also be related to decreasing plant vigor (Oliveira et al., 2006). 'Camino Real' and 'Palomar' showed during the season 1 the lowest levels of titratable acidity, and during the season 2 it was observed for 'Palomar' and 'Portola' fruits.

Due to the low sugar level and to the high acidity, no cultivar in any season (Table 1) reached the SS/AT of at least 8.75 , value recommended for strawberry flavor acceptance (Kader, 1999). The high fruit acidity was probably the main factor compromising SS/AT, mainly in season 2 (Table 1), although the soluble solids content was also lower than recommended. Nevertheless, scientific studies show that 'Camino Real' and 'Albion' fruits can reach higher SS/AT [8.47 in 'Camino Real' (Camargo et al., 2011); 9.13 in 'Camino Real' (Silva, 2011) and 16.26 in 'Albion' (Silva, 2011)]. So, it is possible to assume that it is not recommended to keep strawberry plants in the field for more than 12 months, a usual technology

Table 1. Means of soluble solid content, titratable acidity, soluble solid content/titratable acidity, flesh firmness, and C vitamin content (mg ascorbic acid $100 \mathrm{~g}^{-1}$ fruit) of six strawberry cultivars on growing season 1 (January, February and March) and on growing season 2 (August, September and October) [médias dos teores de sólidos solúveis, acidez titulável, relação do teor de sólidos solúveis pela acidez titulável, firmeza de polpa e teores médios de vitamina C (mg de ácido ascórbico $100 \mathrm{~g}^{-1} \mathrm{de}$ fruto) de frutos de seis cultivares de morangueiro produzidas na época 1 (janeiro, fevereiro e março) e na época 2 (agosto, setembro e outubro)]. Curitiba, UFPR, 2011.

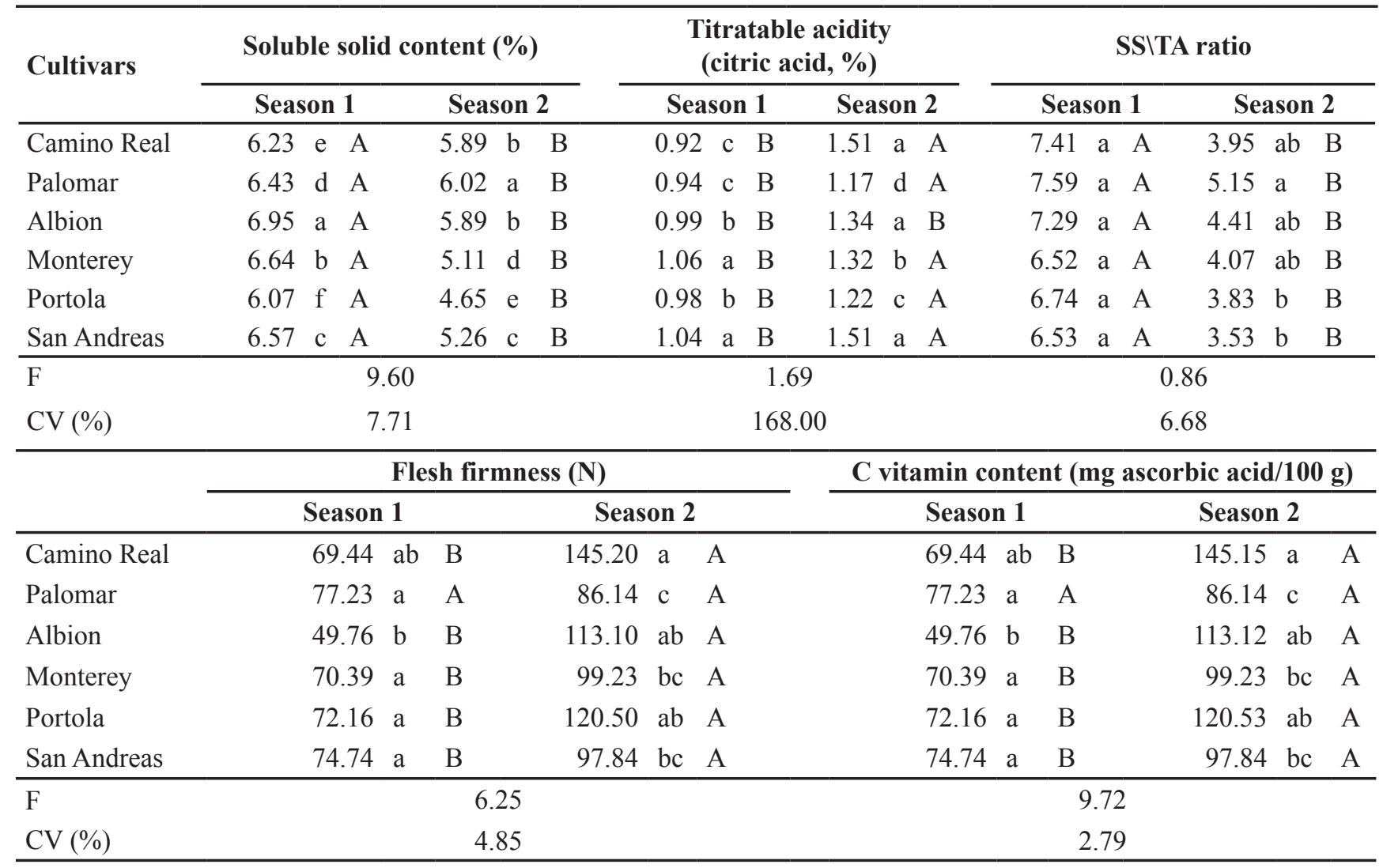

Mean values followed by same lowercase letters in the columns and uppercase in rows do not differ by Tukey test, $\mathrm{p} \leq 0.01$ [médias seguidas de mesma letra minúscula na coluna e maiúscula na linha não diferem estatisticamente entre si pelo teste de Tukey $(\mathrm{p} \leq 0.01)]$. 
Table 2. Means for fruit acidity, aroma, shape, and flesh firmness of six strawberry cultivars on growing season 1 (January, February and March) and on growing season 2 (August, September and October) evaluated by Quantitative Descriptive Analysis [médias das notas atribuídas para acidez, aroma, formato e firmeza de polpa de frutos de seis cultivares de morangueiro produzidas na época 1 (janeiro, fevereiro e março) e na época 2 (agosto, setembro e outubro) e avaliadas por Análise Descritiva Quantitativa]. Curitiba, UFPR, 2011.

\begin{tabular}{|c|c|c|c|c|c|c|c|c|}
\hline \multirow{2}{*}{ Cultivars } & \multicolumn{2}{|c|}{ Aroma } & \multicolumn{2}{|c|}{ Shape } & \multicolumn{2}{|c|}{ Acidity } & \multicolumn{2}{|c|}{ Flesh firmness } \\
\hline & Summer & Winter & Summer & Winter & Summer & Winter & Summer & Winter \\
\hline Camino Real & $6.72 \mathrm{abA}$ & $5.28 \mathrm{~b} \mathrm{~B}$ & 7.95 a $\mathrm{A}$ & $6.59 \mathrm{~b} \mathrm{~B}$ & $7.26 \mathrm{a} \mathrm{A}$ & 7.11 a A & 7.55 a A & $7.20 \mathrm{ab} \mathrm{A}$ \\
\hline Palomar & $6.11 \mathrm{abA}$ & 6.39 a A & 7.44 a A & $7.27 \mathrm{abA}$ & $6.71 \mathrm{ab} \mathrm{A}$ & 6.32 a $\mathrm{A}$ & 7.36 a A & $6.99 \mathrm{~b} \quad \mathrm{~A}$ \\
\hline Albion & 7.49 a A & $6.76 \mathrm{a} \mathrm{B}$ & 7.59 a A & $7.35 \mathrm{abA}$ & $6.77 \mathrm{ab} \mathrm{A}$ & 7.01 a $\mathrm{A}$ & 7.82 a A & $7.24 \mathrm{ab} \mathrm{B}$ \\
\hline Monterey & $6.74 \mathrm{abA}$ & $6.05 \mathrm{abB}$ & 7.55 a A & 7.76 a A & $7.18 \mathrm{ab} A$ & 7.08 a $A$ & 7.50 a A & $7.36 \mathrm{ab} \mathrm{A}$ \\
\hline Portola & $6.23 \mathrm{~b} \mathrm{~A}$ & $6.08 \mathrm{abA}$ & 7.74 a A & $7.54 \mathrm{a} \mathrm{A}$ & $6.37 \mathrm{~b} \quad \mathrm{~A}$ & 6.78 a $\mathrm{A}$ & 7.43 a A & $7.70 \mathrm{a} \quad \mathrm{A}$ \\
\hline San Andreas & $6.86 \mathrm{abA}$ & $6.56 \mathrm{a} \mathrm{A}$ & 7.90 a A & $7.45 \mathrm{a} \mathrm{A}$ & $7.07 \mathrm{ab} A$ & 7.22 a $\mathrm{A}$ & 7.69 a A & $7.56 \mathrm{ab} A$ \\
\hline $\mathrm{F}$ & \multicolumn{2}{|c|}{33.52} & \multicolumn{2}{|c|}{4.49} & \multicolumn{2}{|c|}{0.85} & \multicolumn{2}{|c|}{1.57} \\
\hline CV (\%) & \multicolumn{2}{|c|}{27.30} & \multicolumn{2}{|c|}{29.58} & \multicolumn{2}{|c|}{31.25} & \multicolumn{2}{|c|}{27.83} \\
\hline
\end{tabular}

Mean values followed by same lowercase letters in the columns and uppercase in rows do not differ by Tukey test, $\mathrm{p} \leq 0.01$ [médias seguidas de mesma letra minúscula na coluna e maiúscula na linha não diferem estatisticamente entre si pelo teste de Tukey $(\mathrm{p} \leq 0.01)]$.

applied in CMR. This statement is in agreement with the annual replanting recommendations, although this represents $24 \%$ of the production costs (Oliveira \& Scivittaro, 2006). The annual replanting recommendation prevents the accumulation of pests and diseases from one year to another (Oliveira et al., 2006), and also certainly maintains plants vigorous. However, even with the low ratio (SS/AT), the local consumers buy these products routinely, clearly demonstrating the need for implementation of more sensory analysis to improve fruit quality.

Strawberry fruits with flesh firmness lower than $83.55 \mathrm{~N}$ are considered too soft, and when it is higher than 135.16 $\mathrm{N}$ are considered too firm (Conti et al., 2002). In this way, at season 1 all cultivars produced fruits considered too soft (Table 1). This parameter is very important because it affects the postharvest shelf life and transport damage occurrence (Bieniasz et al., 2012). These results may be due to high temperatures and high relative humidity in summer time (data not presented), which give fruits a less firm texture (Filgueira, 2008). Among all fruits harvested during season 1 'Albion' was that with softest firmness, and should be chosen with a lot of care, mainly when the product final destination is to distant markets.

All fruits showed lower $\mathrm{C}$ vitamin content during season 1 than during the season 2 (Table 1). This result can be explained because $\mathrm{C}$ vitamin is heat-labile, and easily oxidized if exposed to high temperature (Calegaro et al., 2002). Higher $C$ vitamin content during the coldest season was also found in strawberry fruits by Pineli et al. (2012). 'Palomar' and 'Portola' fruits showed higher $\mathrm{C}$ vitamin content in both growing seasons (Table 1). This suggests that these cultivars can be promising when the cultivation purpose is focused on fruits antioxidant potential, such as verified in strawberry juices (Wan \& Lin, 2003). C vitamin content was similar to the content found by Malgarim et al. (2006), and below to the values found by Rocha et al. (2008).

The physiological behavior of shortday strawberry cultivars is correlated with temperature and photoperiod, and as the photoperiod decreases, flowering and fruiting are stimulated (Filgueira, 2008). However, 'Camino Real' and 'Palomar' (both short-day cultivars) were not better than the day-neutral cultivars, grown during the season 2. This demonstrates the high dayneutral cultivars adaptation. Day-neutral cultivars grown during season 1 were expected to be better than short-day cultivars, but this did not occur (Table 1). Different cultivars performances within the same planting season can be explained by the genotypic components and its environment interaction. Local weather conditions, such as rain, light intensity, and temperature, probably affected the strawberry cultivar performance, as well as found by Pineli et al. (2012).

Sweetness sensory scores were smaller than those assigned in other sensory attributes analyzed, and they were similar during the two growing seasons, from 5.50 to 6.48 (Table 2). Similar behavior was observed on fruit flavor, with scores ranging from 5.87 to 6.72 . These results for sweetness and taste reflect the low soluble solids content (Table 1). It agrees with Resende et al. (2008) who evaluated strawberry cultivars ratios (SS/TA) and fruits consumer's acceptability. They observed that higher ratios (SS/TA) were associated with better fruit flavor perception.

Sensory analysis did not verify acidity differences between the two growing seasons (Table 2), such as was verified by chemical analysis (Table 1 ). As could be expected, scores assigned for this parameter (Table 2) were almost as low as those assigned to sweetness and flavor. This demonstrates that even though the local market consumes the product, it does not present a good acceptability.

Minimum differences were verified on the fruits aroma in both seasons (Table 2), but apparently there was a trend showing that this parameter was 
Table 3. Means for $\mathrm{K}, \mathrm{Ca}, \mathrm{Mg}, \mathrm{Fe}, \mathrm{Mn}$ and $\mathrm{Zn}$ content on six strawberry cultivars [teores médios de $\mathrm{K}, \mathrm{Ca}, \mathrm{Mg}, \mathrm{Fe}, \mathrm{Mn}$ e $\mathrm{Zn}$ presentes em seis cultivares de morangueiro]. Curitiba, UFPT, 2011.

\begin{tabular}{lcccccc}
\hline Cultivars & $\begin{array}{c}\mathbf{K} \\
(\mathbf{g} / \mathbf{k g})\end{array}$ & $\begin{array}{c}\mathbf{C a} \\
(\mathbf{g} / \mathbf{k g})\end{array}$ & $\begin{array}{c}\mathbf{M g} \\
(\mathbf{g} / \mathbf{k g})\end{array}$ & $\begin{array}{c}\mathbf{F e} \\
(\mathbf{m g} / \mathbf{k g})\end{array}$ & $\begin{array}{c}\mathbf{M n} \\
(\mathbf{m g} / \mathbf{k g})\end{array}$ & $\begin{array}{c}\mathbf{Z n} \\
(\mathbf{m g} / \mathbf{k g})\end{array}$ \\
\hline Camino Real & $16.99 \mathrm{~b}$ & $0.33 \mathrm{bc}$ & $1.08 \mathrm{~b}$ & $21.76 \mathrm{c}$ & $14.91 \mathrm{~d}$ & $5.88 \mathrm{~b}$ \\
Palomar & $20.59 \mathrm{a}$ & $0.39 \mathrm{a}$ & $1.33 \mathrm{a}$ & $23.35 \mathrm{c}$ & $20.31 \mathrm{a}$ & $6.79 \mathrm{a}$ \\
Albion & $18.18 \mathrm{~b}$ & $0.29 \mathrm{~cd}$ & $1.01 \mathrm{~b}$ & $26.21 \mathrm{~b}$ & $19.82 \mathrm{a}$ & $5.88 \mathrm{~b}$ \\
Monterey & $16.50 \mathrm{~b}$ & $0.36 \mathrm{ab}$ & $1.00 \mathrm{~b}$ & $16.29 \mathrm{~d}$ & $17.70 \mathrm{~b}$ & $5.85 \mathrm{~b}$ \\
Portola & $16.08 \mathrm{~b}$ & $0.37 \mathrm{a}$ & $1.10 \mathrm{~b}$ & $36.80 \mathrm{a}$ & $16.17 \mathrm{c}$ & $5.86 \mathrm{~b}$ \\
San Andreas & $18.34 \mathrm{ab}$ & $0.25 \mathrm{~d}$ & $1.02 \mathrm{~b}$ & $15.64 \mathrm{~d}$ & $13.00 \mathrm{e}$ & $6.92 \mathrm{a}$ \\
\hline F & 10.05 & 27.36 & 11.85 & 281.90 & 148.60 & 33.54 \\
CV (\%) & 5.84 & 6.09 & 6.69 & 3.96 & 2.75 & 2.85 \\
\hline
\end{tabular}

Mean values followed by same lowercase letter in the columns and uppercase in rows do not differ by Tukey test, $\mathrm{p} \leq 0.01$ [médias seguidas da mesma letra na coluna não diferem estatisticamente entre si pelo teste de Tukey $(\mathrm{p} \leq 0.01)]$.

not so good evaluated in season 1 as it was in season 2. This may have occurred because fruit aroma comes from volatile compounds, which do not manifest themselves under low temperatures with such intensity, due to the lower plants metabolic activity during the cold season. This agrees with observations of Jouquand et al. (2008) that one of the factors affecting strawberry fruits aroma is the harvest season.

Cultivars showed similar fruit shape during the two growing seasons, except for 'Camino Real', harvested during season 2, which corresponds to the winter period (Table 2). Strawberry fruits shape depends on ovules fertilization, and their distribution around the receptacle. In order to obtain fruits without deformations, a uniform pollen distribution on stigmas is needed (Malagodi-Braga, 2002). This distribution can be made by pollinators. Insects absence during flowering period, associated with insufficient pollen amount, can result in fruit deformation (Chang et al., 2001). Presumably the short amount of pollinator insects occurring during the winter season, combined with morphological 'Camino Real' features decreased the flower fertilization, causing fruits malformation and the worst sensory analysis.

Fruits produced during season 1 showed similar flesh firmness (Table 2). However, during season 2 'Palomar' fruits were worse than the others (Table 2). By comparing the analysis, carried out with the texture analyzer (Table 1) and the sensory analysis, a greater accuracy of the mechanical method comparing with sensory ability was identified. These results clearly demonstrate the importance of implementation of the sensory analysis along with the physico-chemical analysis, which in this situation did not reflect the consumer preference.

Mineral composition depends on the evaluated cultivar (Table 3), such as was observed by Tulipani et al. (2008) and Pineli et al. (2012). Under these conditions most nutrients were higher on 'Palomar' fruits except for iron (Fe) level, whose superiority was of 'Portola' fruits. Copper $(\mathrm{Cu})$ was the only mineral that did not present significant differences among cultivars (Table 3 ). This information is very important when the purpose of strawberry production is its nutritional property (Rocha et al., 2008).

Potassium $(\mathrm{K})$, calcium $(\mathrm{Ca})$, iron (Fe), and manganese (Mn) levels (Table 3) were similar to those found in strawberry fruits by Wang \& Lin (2003), and smaller than the values found in strawberry fruits by Rocha et al. (2008). Zinc (Zn) level (Table 3) was lower than that found in strawberry fruits by Wang \& Lin (2003) and Rocha et al. (2008). This can be explained because the nutritional composition is multifactorial, i.e., it is affected by soil, weather, and/ or genetic composition (Darolt, 2003).

\section{REFERENCES}

ANTUNES LEC; RISTOW NC; KROLOW ACR; CARPENEDO S; REISSER JÚNIOR C. 2010. Produtividade e qualidade de cultivares de morangueiro. Horticultura Brasileira 28: 222-226.

BASU A; NGUYEN A; BETTS NM; LYONS TJ. 2014. Strawberry as a functional food: an evidence-based review. Critical Reviews in Food Science and Nutrition 54: 790-806.

BIENIASZ M, MAŁODOBRY M; DZIEDZIC E. 2012. The effect of foliar fertilization with calcium on quality of strawberry cultivars 'Luna' and 'Zanta'. Acta Horticulturae 926: 457-461.

CALEGARO JM; PEZZI E; BENDER RJ. 2002. Utilização de atmosfera modificada na conservação de morangos em pós-colheita. Pesquisa Agropecuária Brasileira 37: 10491055.

CAMARGOLKP; RESENDE JTAV; TOMINAGA TT; KURCHAIDT SM; CAMARGO CK; FIGUEIREDO AST. 2011. Postharvest quality of strawberry fruits produced in organic and conventional systems. Horticultura Brasileira 29: 577-583.

CANTILLANO RFF. 2005. Colheita e póscolheita. In: ANTUNES LEC; DURATE FILHO J. (eds) Sistema de produção do morango. Sistemas de Produção. Embrapa Clima Temperado.

CANTILLANO RFF; ÁVILA JMM; PERALBA MCR; PIZZOLATO TM; TORALLES RP. 2012. Actividad antioxidante, compuestos fenólicos y ácido ascórbico de frutillas en dos sistemas de producción Horticultura Brasileira 30: 620-625.

CHANG YD; LEE MY; MAH Y. 2001. Pollination on strawberry in the vinyl house by Apis mellifera and A. cerana. Acta Horticulturae 561: 257-262.

CONTI JH; MINAMI K; TAVARES FCA. 2002. Produção e qualidade de frutos de diferentes cultivares de morangueiro em ensaios conduzidos em Atibaia e Piracicaba. Horticultura Brasileira 20: 10-17.

DAROLT MR. 2003. Comparação da qualidade do alimento orgânico com o convencional. In: STRIGHETA PC; MUNIZ JN (eds). Alimentos orgânicos: produção, tecnologia e certificação, 1 ed. Viçosa: UFV.

DUTCOSKY SD. 2007. Análise Sensorial de Alimentos. Curitiba: Coleção Exatas, $4 \mathrm{p}$.

FERREIRA VLP; ALMEIDA TCA; PETTINELLI MLCV; SILVA MAAP; CHAVES JBP; BARBOSA EMM. 2000. Análise sensorial: testes discriminativos e afetivos. Manual: série qualidade. Campinas: SBCTA, 127.

FILGUEIRA FAR. 2008. Novo Manual de olericultura. $3^{\mathrm{a}}$. ed., Viçosa: UFV. 421p.

HORWITZ W; LATIMER GW. 2005. Official methods of analysis of the Association of Official Analytical Chemistry. $18^{\text {th }}$ ed. Washington, 1015p.

JOUQUAND CE; CHANDLER C; PLOTTO A; GOODNER K. 2008. A sensory and chemical analysis of fresh strawberries over harvest dates and seasons reveals factors that affect 
eating quality. Journal of American Society of Horticultural Science 133: 859-867.

KADER AA. 1999. Fruit maturity, ripening, and quality relationships. Acta Horticulturae 485: 203-208.

MALAGODI-BRAGA KS. 2002. Estudo de agentes polinizadores em cultura de morango (Fragaria x ananassa). São Paulo: USP. 104p. (Tese doutorado).

MALGARIM MB; CANTILLANO RFF; COUTINHO EF. 2006. Sistemas e condições de colheita e armazenamento na qualidade de morangos cv. Camarosa. Revista Brasileira de Fruticultura 28: 185-189.

MARTINS APL; REISSMANN CB. 2007. Material vegetal e as rotinas laboratoriais nos procedimentos químico analíticos. Scientia Agraria 8: 1-17.

OLIVEIRA RP; SCIVITTARO WB. 2006. Desempenho produtivo de mudas nacionais e importadas de morangueiro. Revista Brasileira de Fruticultura 28: 520-522.

OLIVEIRA RP; SCIVITTARO WB. 2008. Produção de morangueiro da cv. Camino Real em sistema de túnel. Revista Brasileira de Fruticultura 30: 681-684.

OLIVEIRA RP; SCIVITTARO WB. 2009.
Produção de frutos de morango em função de diferentes períodos de vernalização das mudas. Horticultura Brasileira 27: 91-95.

OLIVEIRA RP; SCIVITTARO WB; WREGE MS; UENO B; CASTRO LAS. 2006. Otimização da produção nacional de mudas de morangueiro. EMBRAPA(Boletim Técnico 162), 28p.

PINELI LLO; MORETTI CL; RODRIGUES JSQ; FERREIRA DB; CHIARELLO MD. 2012. Variations in antioxidant properties of strawberries grown in Brazilian Savannah and harvested in different seasons. Journal of the Science of Food and Agriculture 92: 831-838.

RESENDE JTV; CAMARGO LKP; ARGANDOÑA EJS; MARCHESE A; CAMARGO CK. 2008. Sensory analysis and chemical characterization of strawberry fruits. Horticultura Brasileira 26: 371-374.

ROCHA DA; ABREU CMP; CORREAA AD; SANTOS CD; FONSECA EWN. 2008. Análise comparativa de nutrientes funcionais em morangos de diferentes cultivares da região de Lavras-MG. Revista Brasileira de Fruticultura 30: 1124-1128.

SILVA TP. 2011. Características produtivas $e$ físico-químicas de frutos de morangueiro orgânico cultivado com o uso de extrato de algas. Curitiba: UFPR. 123p. (Dissertação mestrado).

SILVA PA; ABREU CMP; ASMAR SA; CORREA AD. 2013. Quality evaluation of strawberries grown in the region of Lavras, Minas Gerais State. Acta Scientiarum 35: 777-782.

TULIPANI S; MEZZETTI B; CAPOCASA F; BOMPADRE S; BEEKWILDER J; VOS CH; CAPANOGLU E; BOVY A; BATTINO M. 2008. Antioxidants, phenolic compounds, and nutritional quality of different strawberry genotypes. Journal of Agricultural and Food Chemistry 56: 696-704.

VICENTE E; VARELA P; SALDAMANDO L; ARES G. 2014. Evaluation of the sensory characteristics of strawberry cultivars throughout the harvest season using projective mapping. Journal of the Science of Food and Agriculture 94: 591-599.

WANG SW; LIN HS. 2003. Compost as a soil supplement increases the level of antioxidant compounds and oxygen radical absorbance capacity in strawberries. Journal of Agricultural and Food Chemistry 51: 6844-6850. 